\title{
REPRODUCTION AND FOOD HABITS OF THE LINED SEAHORSE, Hippocampus erectus (TELEOSTEI: SYNGNATHIDAE) OF CHESAPEAKE BAY, VIRGINIA
}

\author{
TEIXEIRA, R. L. ${ }^{1}$ and MUSICK, J. A. ${ }^{2}$ \\ ${ }^{1}$ Museu de Biologia Prof. Mello Leitão, Av. José Ruschi, 4, CEP 29650-000, Santa Teresa, ES, Brazil \\ ${ }^{2}$ Department of Fishery Science, School of Marine Science, The College of William and Mary, Gloucester Point, \\ VA 23062, USA \\ Correspondence to: Rogério L. Teixeira, Rua Bernardino Monteiro, 75, Centro, CEP 29650-000, Santa Tereza, ES, \\ Brazil, e-mail: teixeira@sigma.tropical.com.br \\ Received August 26, 1999 - Accepted April 5, 2000 - Distributed February 28, 2001
}

(With 7 figures)

\begin{abstract}
The reproductive and feeding biology of the lined seahorse, Hippocampus erectus, was studied in Chesapeake Bay. Seahorses are monogamous, and males incubate the eggs received from females in a closed brood pouch (= marsupium). Females do not play any parental care after mating. Total sex ratio and the operational sex ratio was strongly skewed toward females. Males and females had similar number of eggs/embryos and hydrated oocytes, respectively. The number of eggs/embryos found in the male brood pouch varied from 97 to 1,552 (fish from 80 to $126 \mathrm{~mm} \mathrm{TL}$ ), whereas the number of hydrated oocytes in female varied from 90 to 1,313 (fish from 60 to $123 \mathrm{~mm} \mathrm{TL}$ ). Both, the number of eggs/embryos and hydrated oocytes were better linearly correlated to total weight than to total length. The small snout and mouth size limits the feeding of the lined seahorse to small prey size. Amphypods were the predominant food items found in the guts, especially Ampithoe longimana, Gammarus mucronatus, and Caprella penantis. The lined seahorse is not abundant in Chesapeake Bay, but keeps a breeding population which is probably brought inside the bay by currents on drifting vegetation. Chances to find a partner may be difficult because of its low abundance, due to turbid waters, and its sedentary behavior.
\end{abstract}

Key words: parental care, fecundity, fertility, amphipods, estuary.

\section{RESUMO}

\section{Reprodução e hábito alimentar do cavalo-marinho Hippocampus erectus (Teleostei:} Syngnathidae) de Chesapeake Bay, Virgínia

A biologia reprodutiva e alimentar do cavalo-marinho Hippocampus erectus foi estudada no estuário de Chesapeake Bay, Virgínia. Cavalos-marinhos são monógamos, sendo que o macho incuba os ovos recebidos da fêmea em uma bolsa incubadora fechada (= marsúpio). As fêmeas não desempenham qualquer cuidado com a prole após a fecundação. A razão sexual total e operacional foi fortemente direcionada para as fêmeas. Machos e fêmeas tiveram similares números de ovos/embriões e ovócitos hidratados, respectivamente. O número de ovos/embriões na bolsa incubadora dos machos variou de 97 a 1.552 (exemplares de 80 a $126 \mathrm{~mm} \mathrm{CT}$ ), enquanto o número de ovócitos hidratados nas fêmeas variou de 90 a 1.313 (exemplares de 60 a $123 \mathrm{~mm} \mathrm{CT}$ ). Tanto para os machos quanto para as fêmeas o número de ovos/embriões e ovócitos hidratados foi mais correlacionado com o peso do que com o comprimento total. O comprimento do focinho e a amplitude bucal limitam o cavalo-marinho a explorar pequenas presas. Anfípodas predominaram na dieta, especialmente Ampithoe longimana, Gammarus mucronatus e Caprella penantis. O cavalo-marinho não é uma espécie abundante em Che- 
sapeake Bay, mas mantém uma população reprodutiva. As chances para encontrar um parceiro são pequenas, devido à baixa abundância, às águas túrbidas e ao comportamento sedentário da espécie.

Palavras-chave: cuidado paternal, fecundidade, fertilidade, anfípodas, estuário.

\section{INTRODUCTION}

The lined seahorse, Hippocampus erectus Perry 1810, occurs from Nova Scotia to Uruguay, being most common in deeper water where vegetation is abundant, and can tolerate a marked range in salinity and temperature (Böhlke, 1982). Male seahorses have sex role reversal. Fertilization and incubation of oocytes received from female takes place in a sac-like brood pouch (= marsupium) located under the tail. After oocytes transference, females do not play any role in parental care. Male brood pouches in seahorses are the most advanced among all syngnathid species, opening only through an anteromesial pore.

Vincent et al. (1992) contested the fact that the seahorse, Hippocampus fuscus, is sex role reversed. These authors pointed out that the males of this seahorse are the predominant competitor for access to mates: males exhibit higher levels of behavior patterns, and males have the two most overtly aggressive behaviors in courtship, such as tail wrestling and snapping with the snout. The point of view presented by Vincent et al. (1992), that sex role reversal is not synonymous of parental care in syngnathids, creates confusion about understanding sex role reversal. We will follow the traditional and simplest idea that male syngnathids have a brood pouch, which protect, osmoregulate and aerate the eggs in compartments located in a "placenta" (Linton \& Soloff, 1964), which should be a female prerogative. Consistent to this idea, Masonjones \& Lewis (1966) observed that the dwarf seahorses, Hippocampus zosterae, are not courtship-role reversed, as previously assumed.

There is little information on the biology of the lined seahorse. Fish (1952) reported underwater sound production for this seahorse. Linton \& Soloff (1964) developed a physiological study of the male brood pouch. They found that the pouch provides optimum ionic and osmotic conditions for eggs/ embryos development. Hildebrand \& Schroeder (1928) cited that $H$. hudsonius (= H. erectus) is not very common in Chesapeake Bay, it can reach $150 \mathrm{~mm}$, and its food habits appears to consist of small crustaceans. Böhlke (1982) cited that the usual number of eggs in the brood pouch varies from 250-400, and copepods, amphipods, and other small crustaceans represented the principal prey for this seahorse. James \& Heck (1994) observed that variation in seagrass structural complexity appears to have little effect on the foraging of the "sit and wait" visual predator lined seahorse, whereas variation in light level produces significant shifts in capture rates.

This study attempts to assess the abundance, and reproduction and food habits of the lined seahorse in Chesapeake Bay, with particular focus on the lower York River estuary.

\section{MATERIAL AND METHODS}

The lined seahorse was collected with several fishing gears and in many different localities in the lower Chesapeake Bay, Virginia. Most of them were collected in the lower York River, at stations, which support extensive beds of submerged aquatic vegetation (Fig. 1). The dominant eelgrass is Zostera marina, which undergoes seasonal and annual fluctuations in distribution and abundance, showing higher biomass during the spring and summer, and almost disappearing during the winter (Orth \& Moore, 1984).

For the biological analysis, samples were taken from May through September 1992 primarily with a $3 \mathrm{~mm}$ mesh dip net during low slack water between Sarah's' Creek and the Coleman bridge (Station A), at approximately $37^{\circ} 24^{\prime} \mathrm{N}, 7^{\circ} 58^{\prime} \mathrm{W}$ (Fig. 1). Samples were taken at depth shallower than $1 \mathrm{~m}$. Periodicity of dip net samples varied from month to month. Additional samples were taken with: 1) A $10 \mathrm{~m}$ semi-balloon otter trawl. Each tow had a duration of five minutes at a speed of approximately 2.5 knots. The trawl survey program consists on a monthly (excepting February) random stratified design survey of the lower Chesapeake Bay, and fixed station mid-channel transects in each of the three major Virginia tributaries: the York, James, and Rappahannock rivers (Bonzek et al., 1993). 


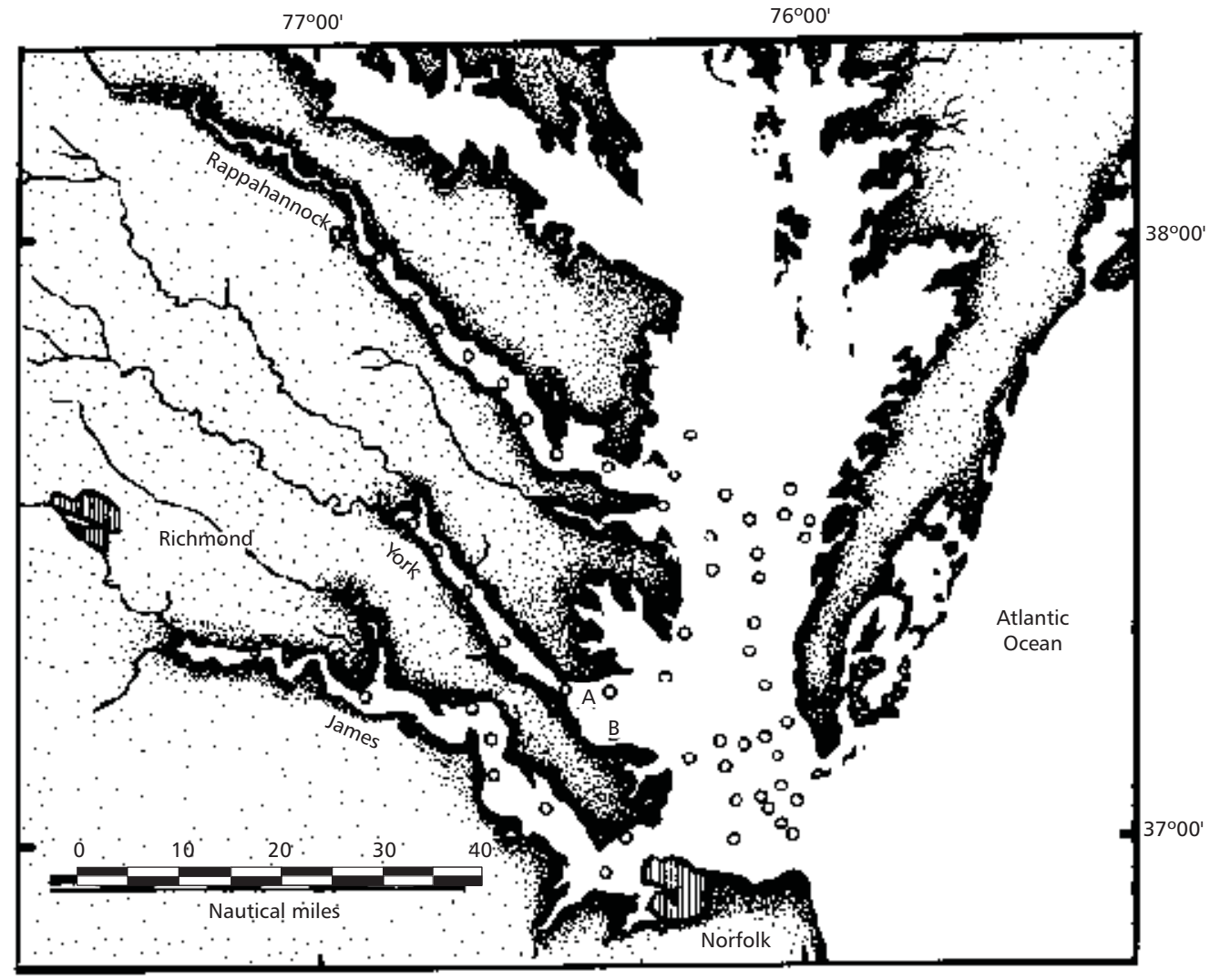

Fig. 1 - Map of the study area in Chesapeake Bay from May 1992 through August 1994 by the trawl survey program (o), and in the lower York River with dip net (Station A) and crab scrape (Station B).

Trawl survey samples were taken from May 1992 through August 1994, and for the biological analysis, only the fish saved by the trawl survey staff were used; 2) A crab scrape apparatus, 0.5 $\times 1.5 \mathrm{~m}$ with $5 \mathrm{~mm}$ mesh size, was used from June through August 1993 (Station B), and was sporadically used in other months.

Trawl survey data from January 1988 through December 1993 was used to observe abundance, and the relationship to salinity and temperature. Between years, abundance was compared by oneway analyses of variance (ANOVA).

Fish were preserved in $10 \%$ formalin for a maximum of $24 \mathrm{~h}$, and then washed and transferred to $70 \%$ ethanol. Laboratory procedures included: identification of species based on Böhlke (1982); measurement of each specimen for total length (TL in $\mathrm{mm}$ ), from the top of head to the tip of tail where the tail is straightened and the head oriented per- pendicular to the longitudinal axis of the tail (Böhlke, 1982); total body and gonad weights $(0.001 \mathrm{~g})$ were also recorded. Ovary weight $(0.001 \mathrm{~g})$ was recorded to calculate the gonadosomatic index (GSI = ovary weight/total weight $\times 100$ ).

The number of eggs or embryos in the male's brood pouch and the number of pre hydrated oocytes in the ovaries were counted for fecundity and fertility comparisons between males and females. The following scale was used to separate different eggs/embryos stages: 0 - non pregnant males; 1 eggs newly deposited in the pouch; 2 - embryos in the beginning stage of development or still containing yolk sac; and 3 - embryos without yolk sac, ready to be released. Analysis of covariance (ANCOVA) was employed to test slopes between cases. Data analyses were performed on log transformed data due to inequality of variances. $\log$ transformations were employed after testing for 
homogeneity of variances using the Bartlett's test (SAS Institute, 1985).

Only the first portion of the guts was used for assessing the diet of the lined seahorse. Prey were identified to the lowest taxon wherever possible, and quantified by frequency of occurrence (\%F.O.) and number $(\% \mathrm{~N})$. For assessing possible variation in the diet, specimens were divided in three length groups: 1) small ( $<60 \mathrm{~mm} \mathrm{TL}) ; 2)$ mid sized (60-99 mm TL); and 3) large (>99 mm TL).

\section{RESULTS}

The trawl survey program collected 448 lined seahorses from January 1988 through December
1993. No significant differences were found in abundance among years (ANOVA: $\mathrm{F}_{1,278}=1.15$; P > 0.34) (Fig. 2A). Pooled monthly data showed that abundance increased from April to June, and from September to November (Fig. 2B), while only a few specimens were collected during the winter months. The second peak in abundance from September to November seems to be related to the recruitment of juveniles. Lined seahorse occurred in temperatures that ranged from 5.0 to $28^{\circ} \mathrm{C}$, and in salinities from 9.2 to $35.5 \%$. There was no correlation between abundance and these abiotic parameters. A total of 136 seahorses ranging in size from 23 to $126 \mathrm{~mm}$ TL were examined for biological data during the study.
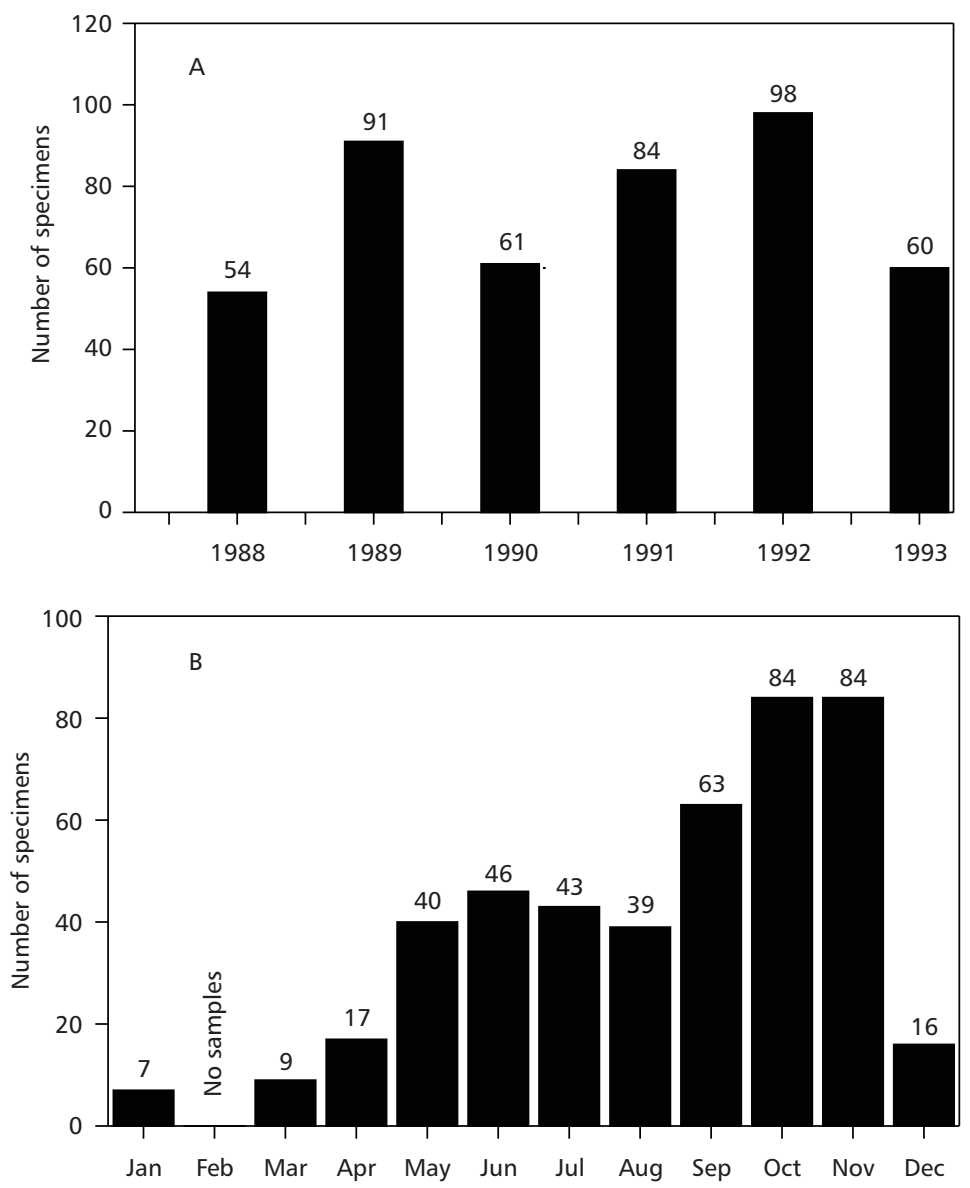

Fig. 2 - Abundance of the lined seahorse in Chesapeake Bay. A) Inter-annual variation in abundance of fish sampled with otter-trawl from January 1988 through December 1993. B) Pooled monthly abundance of fish sampled with otter-trawl from January 1988 through December 1993. 
Total sex ratio was skewed toward females. From the fish examined, 40 were males, 66 females, and the remained immatures. Total male-female sex ratio was $0.6: 1$, which was significantly different from the expected $1: 1$ ratio $\left(\chi^{2}=60.37 ; \mathrm{P}>0.05\right)$. Sixteen males were pregnant, whereas 38 females had running-ripe ovaries. No one of the examined females had ovaries with hydrated oocytes, read to be released. Total length of males and females were similar (Fig. 3). The gonadosomatic index of females larger than $70 \mathrm{~mm}$ TL varied from $0.26 \%$ to $13.44 \%$. Based on pooled data, mean gonadosomatic index varied from $0.51 \%$ in April to $7.33 \%$ in August (Fig. 4). The reproductive period of the lined seahorse in Chesapeake Bay appeared to start in May and finished in October.

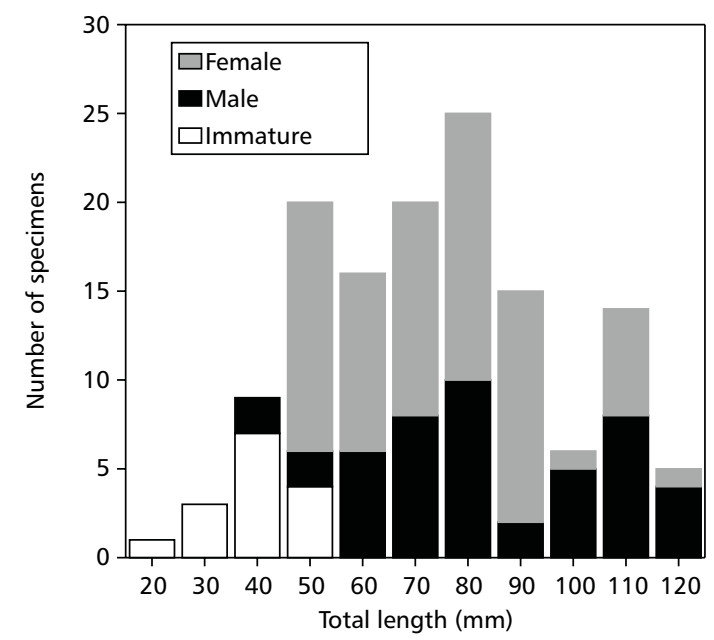

Fig. 3 - Total length frequency distribution of the lined seahorse used to assess the reproductive and feeding biology, collected with different fishing gears from May 1992 through September 1993.

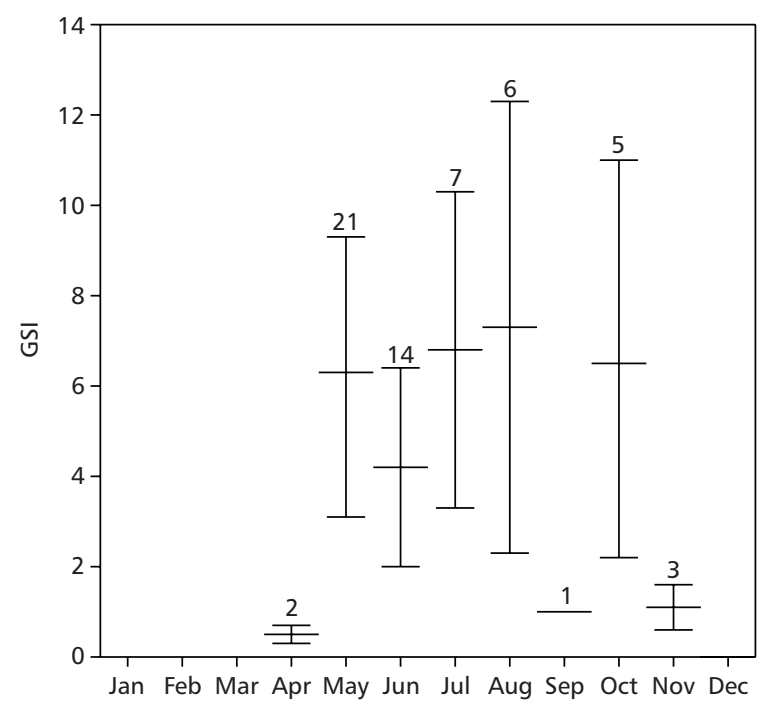

Fig. 4 - Gonadosomatic index (GSI) of females of the lined seahorse of Chesapeake Bay. Bars = mean GSI; vertical lines = standard deviation. 
Males and females showed similar numbers of eggs or embryos and pre-hydrated oocytes, respectively, and number of eggs/embryos and oocytes were correlated with size and weight (Fig. 5A and B). ANCOVA showed that there was no significant difference between number of eggs and number of pre-hydrated oocytes using length as the covariate $\left(\mathrm{F}_{1.38}=0.36 ; \mathrm{P}>0.55\right)$. The number of eggs/embryos counted inside the brood pouch ranged from 97 to $1,552($ mean $=451 ; \mathrm{SD}=232.1)$, in males which varied in total length from 80 to $126 \mathrm{~mm}$. The number of pre-hydrated oocytes in females varied from 90 to 1,313 (mean $=460$; $\mathrm{SD}=$ 253.3), where total length ranged from 60 to 123 $\mathrm{mm}$.
The number of eggs/embryos (E) or pre-hydrated oocytes $(\mathrm{O})$ was better correlated with total weight (TW) than total length (TL). The regression equations were:

$$
\begin{aligned}
& E=10.22 T L-604.76\left(n=16 ; r^{2}=0.45 ; P<0.02\right) \\
& E=67.43 T W+16.14\left(n=16 ; r^{2}=0.57 ; P<0.01\right) \\
& O=15.18 T L-865.55\left(n=38 ; r^{2}=0.59 ; P<0.01\right) \\
& O=138.87 T W-30.44\left(n=38 ; r^{2}=0.73 ; P<0.01\right)
\end{aligned}
$$

Non fertilized eggs frequently occurred inside the male brood pouch. They were observed in $50.0 \%$ of the analyzed males, and they represented from $1.72 \%$ to $32.9 \%$ of the total number of eggs/ embryos in the brood pouch.
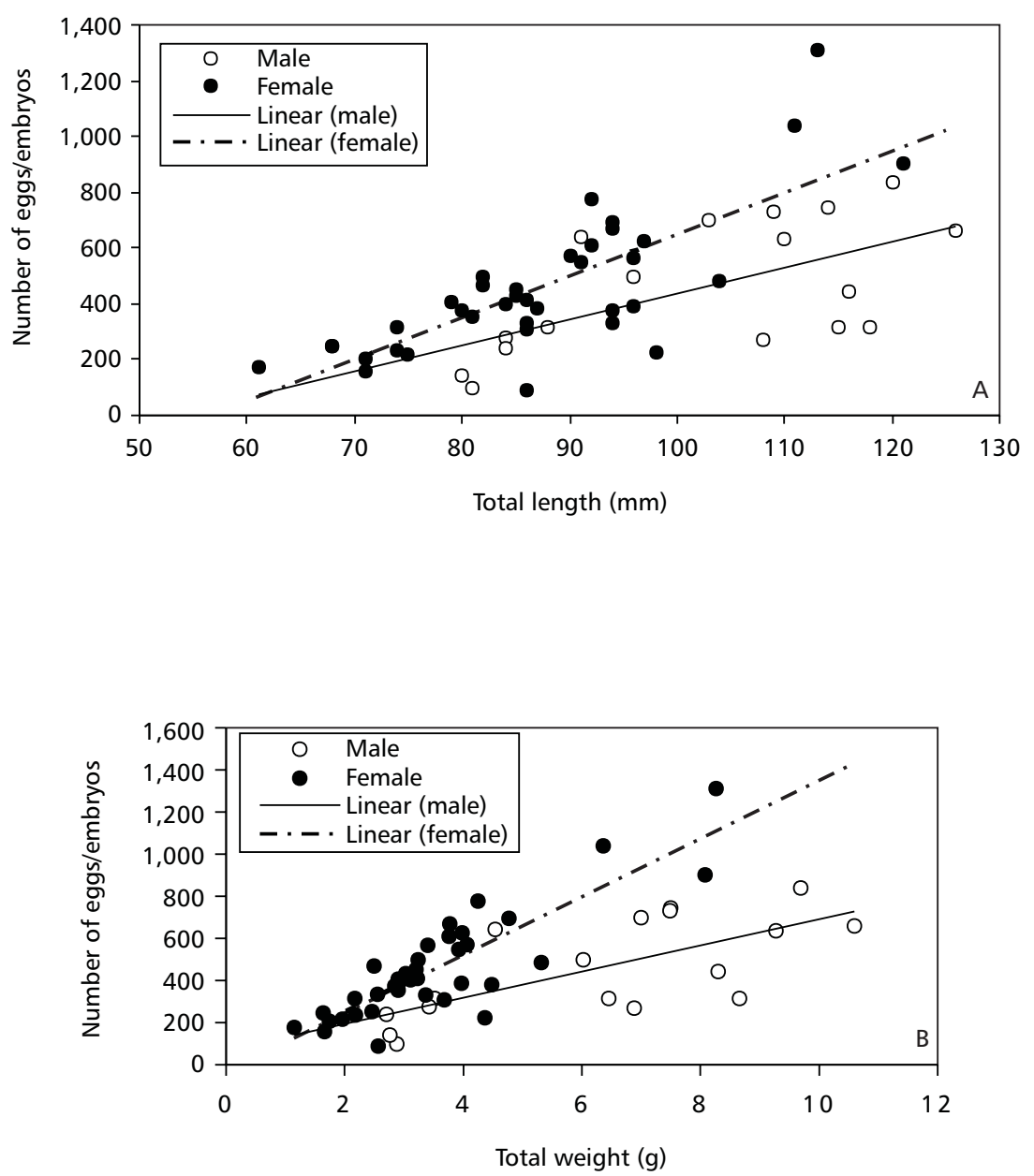

Fig. 5 - Relationship between fecundity and fertility of the lined seahorse of Chesapeake Bay. A) Relationship between number of eggs/embryos or oocytes against total length. B) Relationship between number of eggs/embryos or oocytes against total weight. 
Fertilized eggs in the pouch are irregular but spherical in shape, while pre-hydrated oocytes are cuneiform. Hydrated oocytes may have a shape similar to that of eggs newly deposited in the male pouch. The pre-hydrated oocytes all had similar diameter, evidence that the lined seahorse is a total spawner.

From the fish collected, $133(97.8 \%)$ had full guts. Feeding of the lined seahorse is limited by snout shape and width, as is the case with other syngnathids. Amphipods were the most important prey, followed by copepods. The most important identified amphipods for frequency of occurrence and by numerical abundance in the gut were: Ampithoe longimana, Gammarus mucronatus, Caprella penantis and Stenothoe minuta (Table 1).

Ampithoe longimana was more frequently found, whereas G. mucronatus was the most prey found. Besides some small crustaceans, other groups, such as mollusks and polychaetes, did not represent important items in the diet of the lined seahorse.

Length groups analyzed frequency of prey in the guts, and amphipods were most frequent in all size groups (Figs. 6 and 7). Smaller fish (<60 mm TL) fed mainly on amphipods, with copepods secondarily important. Mid size (60$99 \mathrm{~mm}$ TL) and larger (>99 mm TL) fed almost exclusively on amphipods. Ampithoe longimana was most frequent in the smaller and larger fish gut contents, and G. mucronatus was most frequent in the mid size group.

\section{DISCUSSION}

Relatively few specimens of the lined seahorse occupy Chesapeake Bay. As a weak-swimming fish, probably some individuals are accidentally brought inside the bay by ocean currents, when they are attached to drifting vegetation. Despite the lined seahorse can tolerate a wide range of salinity (Böhlke, 1982; this study), the Chesapeake Bay appears not to be very conducive for this seahorse, even though the estuary furnishes an excellent habitat for shelter and feeding, and this species can breed inside an estuarine habitat. Migratory movements have not been recorded for this seahorse, but they are even more rare in Chesapeake Bay during the winter, especially at the lower York River. Wicklund et al. (1966), observed that during the winter (temperature of $10.6^{\circ} \mathrm{C}$ ) in the Mid-Atlantic Bight, the lined seahorse was found motionless on the bottom, with its prehensile tail straightened, and exhibited no noticeable respiratory movement.

Abundance of the lined seahorse inside Chesapeake Bay did not vary significantly from 1988 through 1993. The results were based on trawl survey stations, which do not sample the main eelgrass beds inside the bay. Sampling of eelgrass beds in the lower Chesapeake Bay by Orth \& Heck (1980), showed that the seahorses were not abundant there, and represented only $0.02 \%$ of all fish collected. Ichthyoplankton samples taken in eelgrass beds in the lower Chesapeake Bay by Olney \& Boehlert (1988), did not find the presence of any newborn seahorses, only larger juveniles and these were low in abundance. Based on the fertility of this seahorse, it is noted that just a single male could release more newborn than the entire number of seahorses collected by the trawl survey program during the six years.

Number of specimens of the lined seahorse inside Chesapeake Bay could also be related to the abundance of seagrass and drifting vegetation, once the syngnathids become dependent on it. Orth $\&$ Moore (1984) pointed out that eelgrass has suffered several historical fluctuations in abundance, and the causes of this decline may be related to changes in water quality, primarily increased eutrophication and turbidity, and diseases.

The number of pre-hydrated oocytes produced by the female lined seahorse is similar to the number of eggs/embryos found in the male brood pouch.

This suggests that similar sized partners should mate, in order to maximize the total number of oocytes present in the female ovary, since the lined seahorse is a total spawner and is monogamous. However, as hydrated oocytes are very ephemeral, and partners with different size could mate, many oocytes may not be transferred to the male brood pouch in the case of a larger female than male, because the number of young is also dependent on male brood pouch carrying capacity. On the other hand, if the male is larger than the female, a female will not have enough hydrated oocytes to fill the male brood pouch. Both cases represent a trade off between timing to mate and maximization of spawn. 
TABLE 1

Food items found in the guts of the lined seahorse, Hippocampus erectus, of Chesapeake Bay. \%F.O. = frequency of occurrency; $\% \mathrm{~N}=$ number of prey.

\begin{tabular}{|c|c|c|}
\hline Prey & \% F.O. & $\% \mathrm{~N}$ \\
\hline \multicolumn{3}{|l|}{ CRUSTACEA } \\
\hline Copepoda & 11.4 & 8.4 \\
\hline Ostracoda & 0.9 & $<0.1$ \\
\hline \multicolumn{3}{|l|}{ Amphipoda } \\
\hline \multicolumn{3}{|l|}{ Ampithoidae } \\
\hline Ampithoe longimana & 35.1 & 13.6 \\
\hline Cymadusa compta & 5.3 & 0.7 \\
\hline \multicolumn{3}{|l|}{ Corophiidae } \\
\hline Cerapus tubularis & 1.7 & 0.4 \\
\hline Corophium tuberculatum & 5.3 & 0.7 \\
\hline \multicolumn{3}{|l|}{ Ischyroceridae } \\
\hline Jassa falcata & 5.3 & 1.6 \\
\hline \multicolumn{3}{|l|}{ Bateidae } \\
\hline Batea catharinensis & 0.9 & $<0.1$ \\
\hline \multicolumn{3}{|l|}{ Gammaridae } \\
\hline Elasmopus levis & 2.6 & 0.4 \\
\hline Gammarus mисronatus & 33.3 & 39.8 \\
\hline Melita appendiculata & 4.4 & 0.7 \\
\hline \multicolumn{3}{|l|}{ Pleustidae } \\
\hline Sympleustes glaber & 0.9 & $<0.1$ \\
\hline \multicolumn{3}{|l|}{ Stenothoidae } \\
\hline Stenothoe minuta & 21.9 & 7.4 \\
\hline \multicolumn{3}{|l|}{ Ampeliscidae } \\
\hline Ampelisca vadorum & 0.9 & $<0.1$ \\
\hline Ampelisca verrilli & 1.7 & 0.3 \\
\hline \multicolumn{3}{|l|}{ Aoridae } \\
\hline Rudilemboides sp. & 0.9 & 0.2 \\
\hline \multicolumn{3}{|l|}{ Caprellidae } \\
\hline Caprella penantis & 22.8 & 12.6 \\
\hline Other Caprellids & 13.2 & 2.1 \\
\hline Unidentified Amphipods & 21.9 & 8.5 \\
\hline Amphipod Remains & 4.4 & \\
\hline \multicolumn{3}{|l|}{ Isopoda } \\
\hline \multicolumn{3}{|l|}{ Idotheidae } \\
\hline Erichsonella attenuata & 0.9 & 0.2 \\
\hline \multicolumn{3}{|l|}{ Mysidacea } \\
\hline Mysidopsis bigelowi & 0.9 & $<0.1$ \\
\hline Decapoda & & \\
\hline
\end{tabular}


TABLE 1 (Continuation)

\begin{tabular}{|l|c|c|}
\hline Prey & \%F.O. & \% N \\
\hline Palaemonidae & & 0.4 \\
\hline Palaemonetes pugio & 2.6 & 0.3 \\
\hline Palaemonetes vulgaris & 1.7 & \\
\hline Crangonidae & & 0.4 \\
\hline Crangon septemspinosa & 3.5 & \\
\hline Portunidae & & 0.6 \\
\hline Callinectes sapidus (megalopa) & 3.5 & \\
\hline MOLLUSCA & & \\
\hline Gastropoda & & $<0.1$ \\
\hline Cerithiidae & 0.9 & 0.3 \\
\hline Bittium varium & 2.6 & \\
\hline POLYCHAETA & 0.9 & \\
\hline MISCELANEOUS & & \\
\hline
\end{tabular}

This seems to be true, since the search for a mate in the eelgrass beds could take a long time, causing atresia in the hydrated oocytes. The weak relationship obtained between fecundity and fertility (Fig. 2), provides evidence that a male may not always have a full brood pouch.

Gravid females outnumbered available males (with total developed brood pouch) by up to two times. This means that the males are the limiting sex for reproductive success inside Chesapeake Bay. Since seahorses are monogamous (Vincent et al., 1992), most females will not find a mate during the reproductive period. The investment in ovary development for this particular lined seahorse "population" which occupies Chesapeake Bay is therefore a trade-off between the chance of finding a mate and waste of energy. In fact, there is no record in the literature that the ovaries can be recovered after the first mating, or whether males could receive another batch after releasing embryos from the pouch. Newborn seahorses are released by ejection from the brood pouch by body contortions and a pumping action of the pouch. The period of pregnancy may represent a high energetic cost for the male seahorse, which may reach extremes during the time they are giving birth.

Fertility in the lined seahorse may vary in different habitats. Lockwood (1867) reported up to 1,000 juveniles inside the brood pouch. Böhlke
(1992) usually found from 250 to 400 eggs, while pointing out that the results reported by Lockwood (1867) was not confirmed again.

In this study, it was observed that a large female could carry up to 1,000 oocytes, whereas the largest number of eggs/embryos inside the male's brood pouch obtained during this study was 1,552 . The amount of oocytes that can be transferred to the male brood pouch depends on the male's carrying capacity. The largest specimen recorded by Böhlke (1992) was 173 mm TL, much longer than that observed in this study: $126 \mathrm{~mm}$ TL. Fecundity and fertility in the largest specimens during this study was found to exceed 1,000 eggs.

The limitation of prey type in many syngnathid species has been attributed to snout size (and width) by many authors (e.g., Mercer, 1973; Brook, 1977; Teixeira \& Musick, 1995). In Chesapeake Bay, the food habits of the lined seahorse mostly resemble that of the northern, Syngnathus fuscus, and the dusky pipefish S. floridae (Mercer, 1973; Teixeira \& Musick, 1995). Amphipods were the most important prey for all length groups analyzed, but copepods are probably more important for the newborn seahorse.

Acknowledgments - This paper was funded by Conselho Nacional do Desenvolvimento Científico e Tecnológico (Process N. 302657/87-8). We appreciate Thomas A. Munroe, Romuald N. Lipcius, Robert J. Orth, and Wolfgang Vogelbein for useful criticisms of an earlier version of the manuscript. 


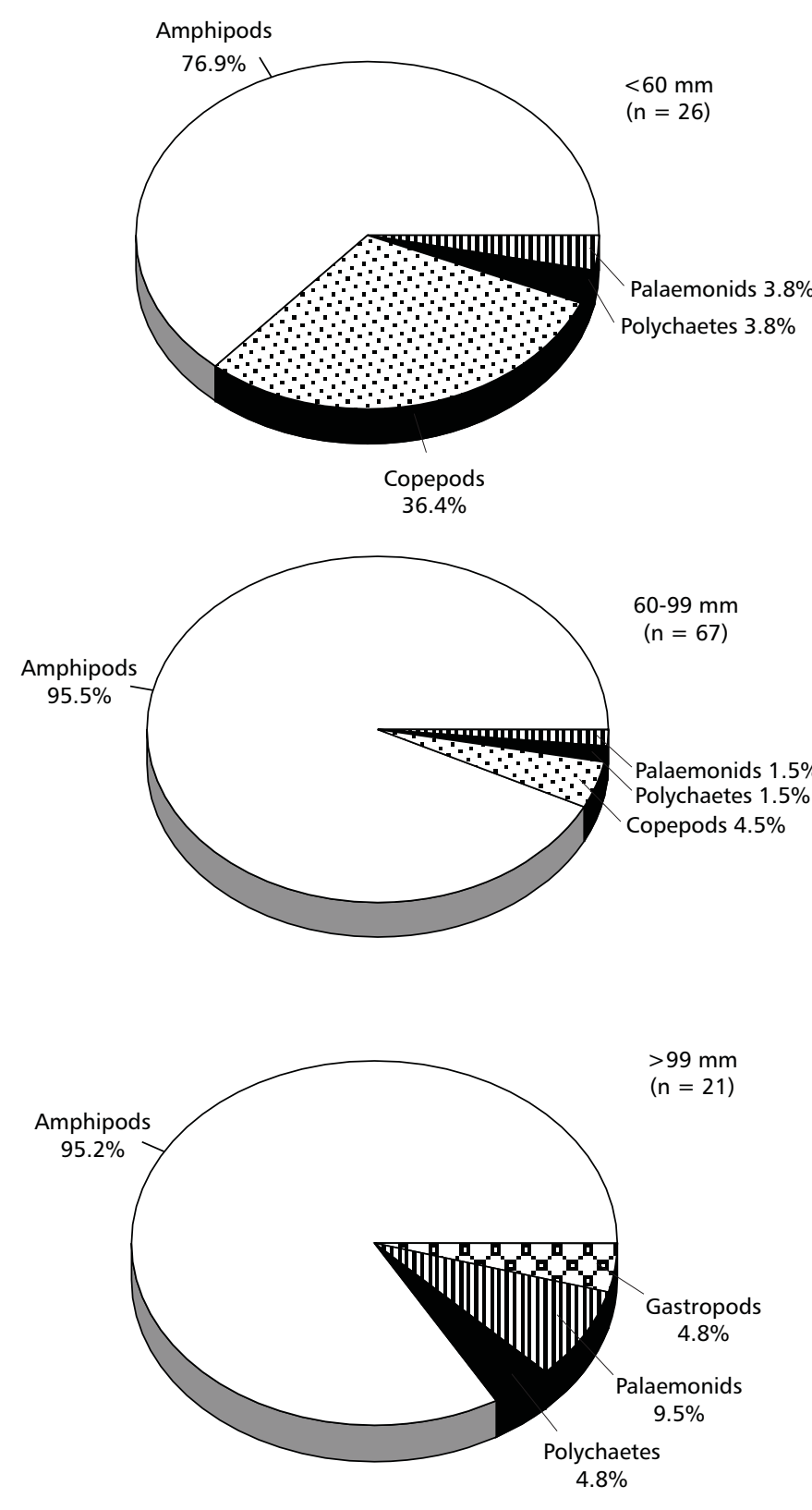

Fig. 6 - Food items most frequently found in the guts of the lined seahorse of Chesapeake Bay. 

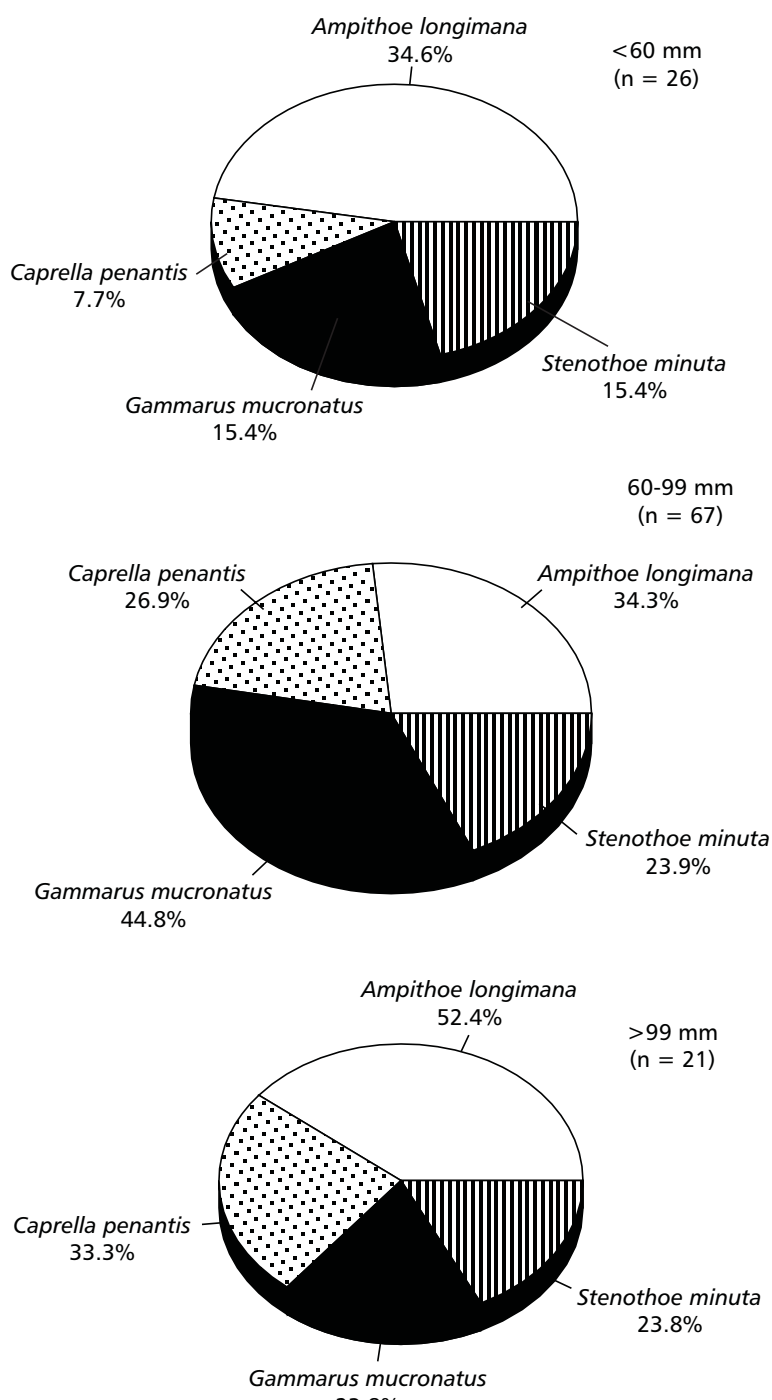

$23.8 \%$

Fig. 7 - Amphipod species identified the guts of the lined seahorse of Chesapeake Bay.

\section{REFERENCES}

BONZEK, C. F., GEER, P. J., COLVOCORESSES, J. A. \& HARRIS, R. E. Jr., 1993, Juvenile finfish and blue crab stock assessment program. Special Scientific Report, College of William and Mary, VIMS, 1992(124): 1-217.

BROOK, I., 1977, Trophic relationships in a seagrass community (Thalassia testudinum), in Card Sound, Florida. Fish diets in relation to macrobenthic and cryptic faunal abundance. Trans. Amer. Fish. Soc., 106: 219-229.
FISH, M. P., 1952, The production of underwater sound by the northern seahorse, Hippocampus hudsonius. Copeia, 1952: 98-99.

JAMES, P. L. \& HECK, K. L., Jr., 1994, The effects of habitat complexity and light intensity on ambush predation within a simulated seagrass habitat. J. Exp. Mar. Biol. Ecol., 176: 187-200.

HILDEBRAND, S. F. \& SCHROEDER, W. C., 1928, The fishes of Chesapeake Bay. Bull. U. S. Bur. Fish., 43: 1388 
LINTON, J. R. \& SOLOFF, B. L., 1964, The physiology of the brood pouch of the male seahorse, Hippocampus erectus. Bull. Mar. Sci. Gulf Caribb., 14: 45-61.

LOCKWOOD, S., 1867, The seahorse (Hyppocampus hudsonius) and its young. Amer. Nat., 1(5): 225-234.

MASONJONES, H. D. \& LEWIS, S. M., 1996, Courtship behavior in the duarf seahorse, Hippocampus zosterae. Copeia, 1966(3): 634-640.

MERCER, L. P., 1973, The comparative ecology of two species of pipefish (Syngnathidae) in the York River, Virginia. M. Sc. Thesis, Virginia Institute of Marine Science, The College of William and Mary, 37p.

OLNEY, J. E. \& BOEHLERT, G. W., 1988, Nearshore ichthyoplankton associated with seagrass beds in the lower Chesapeake Bay. Mar. Ecol. Prog. Ser., 45: 33-43.

ORTH, R. J. \& MOORE, K. A., 1984, Distribution and abundance of submerged aquatic vegetation in Chesapeake Bay: an historical perspective. Estuaries, 7(48): 531-540.

ORTH, R. J. \& HECK, K. L. Jr., 1980, Structural components of eelgrass (Zostera marina) meadows in the lower Chesapeake Bay-Fishes. Estuaries, 3(4): 278-288.
SAS INSTITUTE, INC., 1985, SAS User's Guide: Statistics, Version 5 Edition. Cary, North Carolina, 956p.

TEIXEIRA, R. L. \& MUSICK, J. A., 1995, Trophic ecology of two congeneric pipefishes (Syngnathidae) of the lower York River, Virginia. Environ. Biol. Fish., 43: 295-309.

VARI, R. P., 1982, The Seahorses (Subfamily Hyppocampinae). In: J. E. Bohlke (ed.), Fishes os the Western North Atlantic. Memoir Sears Foundation for Marine Research, Yale University, Number One, Part Eight, New Hsven, 198 pp.

VINCENT, A., AHNESJÖ, I., BERGLUND, A. \& ROSENQVIST, G., 1992, Pipefishes and seahorses: are they all sex role reversed? TREE, 7(7): 237-241.

WICKLUND, R. I., WILK, S. J. \& OGREN, L., 1968, Observations on wintering locations of the nothern piperfish and spotted seahorse. Underwater Naturalist, 5(2): 26-28. 